\title{
Exploring the Portrayal of Female Voice in 'Heer Ranjha': A Gender-Based Study
}

\author{
${ }^{a}$ Tazanfal Tehseem, ${ }^{b}$ Rabia Faiz, ${ }^{c}$ Musarrat Azher, ${ }^{d}$ Zahra Bokhari \\ ${ }^{a}$ Lecturer, Department of English, University of Sargodha, Pakistan \\ Email: tazanfal.tehseem@uos.edu.pk \\ ${ }^{\mathrm{b}}$ Assistant Professor, Department of English, University of Sargodha, Pakistan \\ Email: rabia.faiz@uos.edu.pk \\ c Assistant Professor, Department of English, University of Sargodha, Pakistan \\ Email: musarrat.azhar@uos.edu.pk \\ ${ }^{\mathrm{d}}$ Lecturer at the Department of English, University of Sargodha, Pakistan
}

\begin{tabular}{ll}
\hline ARTICLE DETAILS & ABSTRACT \\
\hline History: & The present study aims at explicating the theme of love in the folk tale \\
Accepted 15 March 2021 & Heer Ranjha through the discourse stylistics perspective. To do this, \\
Available Online March 2021 & Fairclough (2015) model is employed with a focus on lexical choices. The \\
& metaphors used in the dialogues portraying the theme of love have been \\
& carefully selected, and further the linguistic pattern employed has been \\
Keywords: & significantly discussed to highlight the embedded theme of love as a \\
Fove, Metaphors, Lexical Choices, & dominant human emotion in folk tales. The study also aims at providing \\
JEL Classification: & a richer, more complex and enlightened canvas of feminist theory \\
P36 & highlighting the role of women and power relations between the two \\
& sexes. The data comprises on twenty passages from the translation of \\
DOI: 10.47067/real.v4i1.120 & 'Heer Ranjha' by Usborne (1973) where the translator claims to have \\
& translated the epilogue at full length while the rest of the poem has been \\
& condensed without omitting anything significantly important to the \\
& theme. The study throws light on the language of the folk tale, which \\
& reflects socio-cultural features such as the patriarchic family structure \\
& of the time through the language choices. The flute, a bamboo musical \\
instrument, is a metaphor of love in a dream-like romantic sound. & Finally, this paper helps to develop a better understanding of folktales in \\
a particular socio-cultural background.
\end{tabular}

(C) 2021 The authors. Published by SPCRD Global Publishing. This is an open access article under the Creative Commons AttributionNonCommercial 4.0

Corresponding author's email address: tazanfal.tehseem@uos.edu.pk

\section{Introduction}

Folktales offer a wonderful resource for highlighting traditional socio-cultural values. While, folktales have the capacity to enrich the past but their linkage with the present becomes more rewarding to understand the societal behaviour persistent to the norms. For instance, after seeing Heer, Ranjha accepts a job offered to the poors in the lower social strata and places himself to the lower social hierarchy. 'The herd belongs to my father but you the herder belong to me', (Usborne, 1973), 
Heer dictates him the terms and conditions of his employment. Ranjha, the protagonist, accepts the bindings to help evolve a human relationship which in the end establishes an ultimate gender equality. That reversal of gender role of the time portrays the women more dynamic than the men. With this representation the narrator (Waris Shah) expresses his belief that no enduring relation of love is possible in inequality as love is a choice made out of freedom regardless of the prevailing social customs. The significant essence of this romantic discourse is justified in the exploitative socioeconomic structures. Heer strongly refuses to the patriarchy, besides reflecting an emotional aura she embraces her fate as per the economic needs of her clan.

Through their numerous reproductions and retellings, fairy tales such as Sassi-Punno, Laila Majnu, Shiren-Farhad to name only a few have become widely cherished in the Subcontinent where, the river Chenab flowing through the soils of Punjab for centuries its furious waves narrate the songs of love and affection, and Heer-Ranjha is one of the same. It is partly true and fictional, but it continues to have such powerful hold on the imaginations of rural folk that they allow themselves a willing suspension of disbelief. This story has many narrative versions, but the one that has remained most popular throughout the times is Waris Shah's poetic epic, which was written in 1766. Originally, some characters depicted in the Heer were from socio-religious mix, however, gradually the work took on more of an Islamic assertion. This is the story of two legendry lovers Heer and Ranjha. It recounts how Ranjha, is forced to flee his ancestral home and village because of cruel treatment by his jealous sistersin-law, falls in love with Heer at first sight.

The research signifies the theme of love projected through dialogues and it provides an understanding of love and affection in a folktale and informs the way how to better interpret genderbased discourses. The core area of this research is based on the exploration of the metaphors, along the linguistic patterns adopted at the discourse level to portray true meanings of love. It highlights the importance of feministic theory based in a specific socio-cultural background. The narrator is acknowledged as an expert craftsman for sketching imaginative reality on the canvas in an inspirational use of language. He has the potential to construe his imaginative world through words, which sound perfectly natural. We can see a repertoire of lexical choices at the play which best describes the actions and events in the story.

The character sketch of Heer as portrayed by Waris Shah offers a tremendous source of literature that construes the real picture of our patriarchal society where the internal dilemma of the woman of time has been reflected in her voice. Similarly, the protagonist is shown to have abandoned the class oppression and gender inequality. The narrator overwhelmingly throws light on the social evils of the time such as scattered values, class conflicts and hypocrisies. The heroine presents the symbol of self-acclaimed freedom who fights with the miserable shackles of patriarchal norms. Therefore, the celebrated legend of Heer-Ranjha as an intrinsic part of the magnificent oral literature of the Punjab and has remained a valuable source of inspiration for the academics, artists and the historian who are interested in digging out deeper in our society. To sum up, by writing this legendary epic Waris Shah not has only contributed in to the literary legacy of the region, but also enriched status of Punjabi as a rich language of the verbal art.

The research seeks to explore the following questions:

1. How are metaphors used to portray the theme of love in Heer Ranjha?

2. How are power relations between men and women portrayed throughout the folktale Heer Ranjha? 


\section{Review of Literature}

A number of writers and researchers have worked on the theme of love and based their explorations on gender-based discourses.

Butler (2007) takes feminism as an umbrella term, a set of ideologies or movements to win socio-cultural and political rights of equality for women rejecting the traditional concept of feminism and gender. She rejects the binary categories: men and women defining gender as an attribute not fixed but shifting and changing according to the roles one adopts. Tannen (1994) considers gender difference as an expository experience meant to enhance emotional connection. Her study concludes that American men are more indirect because of weakness or lack of confidence while women of America are more direct than that of men.

Lazar (2007) worked in critical discourse analysis from the feministic perspective and explored gender, power and ideology in discourse seeing it from the lens of inequality and how it exists in different institutional, cultural and geographical contexts. Apart from this, she considered gender as an ideological structure that divides people into two classes; men and women, and these classes are based on domination and subordination.

Bachtarzi (2010) inspects human relations in Lawrence's "Sons and Lovers" to record her attitude towards the causes of failure in human relationships by contextualizing each character in relation to the other characters through the lenses of Oedipus complex and feminism. Cherland (2008) studies gender relations in Harry Potter stories from feminist poststructural perspective.

Foghel (2013) explores the theme of love in Shakespeare's Hamlet questioning how Shakespeare managed not only to exemplify recurrent patterns of love but also recreated them masterfully. Language is an appropriate medium and tool for the representation of love (Mehmood, Amber, Ameer \& Faiz, 2014). Words cannot be taken as decontextualized lexical items but they provide the context for judging the value of any text and reaching towards the truth established through language (White, 2002). According to Mills (1995), the linguistic choices, utilized to show power relations and ideology, position men and women ideologically in the socio-cultural contexts. They may pertain to address global and universal ideas or may limit to a narrower social background (Mehboob, 2015).

Feminist narratology has become a crucial method to analyze a feminist piece of literature. These works have greatly provided insights and motivated this research to enlighten the feministic perspective in folktale, Heer Ranjha. The folktale has been touched by different researchers from different perspectives and the perspective adopted for this study is gender-based in approach. The research would analyze some of the core aspects of feminism theory including power relation existing between men and women, their roles and the roles they perform interchangeably. This paper provides insightful implications for these aspects based on feminism by contributing explorations of abovementioned aspects.

\section{Methodology}

In order to find out the answer of research question, the 'metaphors that demonstrate the theme of love' are selected from the dialogues and their significance with respect to their social and cultural context is explained using Fairclough's three-dimensional model narrowed down to vocabulary section dealing with metaphors only. Lakoff and Johnson (1980) discuss different three distinctive types of metaphors including structural metaphors, ontological metaphors and the orientational metaphors whereas Searle (1980) argues that we need to interpret literal meanings in order to better understand 
the use metaphors. He (ibid) further adds that a set of truth conditions is always determined from the literal meanings. For example, 'The cat is on the mat' gives only a limited meaning potential whether the cat is on the table or not, but when we state that A is B it also implies that A is equal to C (Searcle, 1980).

The selected passages from Usborne (1973) are analysed at three levels; lexical, syntactic and discourse. Tables are drawn to explain the role of lexical as well as syntactic features conveying theme of love and representing female voice in Heer Ranjha.

To answer the research questions about gender roles and power relations, twenty passages have been selected from the translated version of folktale Heer Ranjha by Usborne (1976). The female voice is analysed in connection to socio-cultural context.

\section{Analysis and Discussion}

Metaphors serve to add to critical discourse analysis through argument building in meaning construction of a text in socio-cultural setting (Musolff, 2012). From the vocabulary section suggested by Fairclough (2015), metaphors portraying the theme of love are analysed along with lexical, syntactic and discourse level choices in the following section.

To answer this question, all the dialogues that are significant for the theme of love in the translation of folktale are written below and then with respect to Fairclough's model seventeen metaphors are selected and explained and the description, significance and socio-cultural importance of those metaphors is described.

- "Warsa, I am saddened to see that my efforts have gone waste. I taught both you and Bulleh Shah. He ended up playing with the Sarangi and you have come up with this." After listening the story he spoke out, "Wah Waris Shah, You have strung together precious pearls in a twine of munj."

- "Ah, Waris, nothing can help when eyes meet on the battlefield of love." He murmered to Heer "Life is only a dream and you must abandon the pride of youth and beauty and be prepared to leave the world."

- "Heer lost her command and her pride and rule. She was dust in the ground, her grandeur gone in love and devotion, at the feet of Ranjha."

- "I have found my perfect master, who needs anything else. I belong to my Ranjha, he, my lord and my master." After this what happened, "Ranjha showed his face, brilliant, like the radiance of sun and Heer got up and fell in his feet, her honor now, his."

- Qazi advises to Heer: "Parents are clouds of love and your life would be a dirt road in disobedience of your parents. Being from higher caste and a renowned family it is unbecoming of you her to mingle with family servants like Ranjha."

- Heer reply to Qazi,, "Our souls are the clash of lightnings .You cannot wean away an addict from the drug. It is not possible for me to go away from Ranjha .If it our destiny to be together then who, other than God, can change it"? she added rather philosophically, "True love is a mark that a hot iron burns on to the skin or a spot on a mango fruit. They never go away."

- At the time of Nikah, she talked to her father and Qazi,, "My First nikah was already made with Ranjha in the presence of true Prophet himself and was blessed by God and witnessed by four Angles. When you know that My life to a stranger would be a wild plant then how can you dissolve my first nikah and marry me second time to a stranger."

- Ranjha answer to Bulnath, masters of Jogi,,, "I have understood that love is beggar that's why I want to become a jogi." 
- Ranjha said to Raja Adil,,"Heer is a spotless mirror and a vast ocean of love for me and we both are true lovers."

- When Ranjha heard the news of death of Heer, he says,,, "Love proved a destroyer to her that's why I am going to deep sleep.”

According to Fairclough's three dimensional model, seventeen metaphors in the dialogues are selected and their description, significance and socio-cultural importance is provided below in a systematic way.

- Precious pearls: Adjective (precious) and noun (pearls) are used as a metaphor for the noun. 'Precious pearls' is used in terms of 'deep spiritual meanings'. After completing the story ,when Waris Shah showed to his teacher who was disappointed to see that his most talented student instead of paying attention to religion wrote a love story but when he recited the whole story, his teacher was impressed by the language, intensity of powerful emotion of love, diction, tone, and imagery that he used the word "precious pearls" for the words of story showing the importance of this metaphor corresponding to the theme of love

- Twine of Munj: Twine and munj (noun) are used as metaphors for the usage of theme of love in that particular situation. Twine is a lightweight cord used to make munjas in the Punjab. Here this very metaphor is used by the teacher of Waris Shah for 'the usage of theme of physical love' which means that Waris Shah used the theme of physical love in the folktale "Heer-Ranjha" to portray the deep spiritual love that exist. This metaphor is very significant in another sense that the folktale has deep profound meanings if somenone wants to find in it.

- Battlefield:...Noun(battlefield) is used as a metaphor for love. Love is a battlefield. Battlefield is a place where stress, anger and conflict make one's skin hard and tough to face the difficulties. Love does not begin and end the way we seem to think it does. When there was a first encounter of Heer and Ranjha, this word was spoken by Ranjha which means that battlefield of love is also like other battlefields where no one would be there to help you, where you are not sure when it begins and when it ends, there are no promises at all. This very metaphor is used to highlight the theme of love in the sense that love begins and ends naturally.

- Dream: Here noun (dream) is used as a metaphor for life. Life is a dream and where all the happenings are temporary. Everything here is a product of your own mind. This metaphor is used when Ranjha meets Heer for the first time and says this life is not real life and it will be lost. As far as the context of this metaphor is concerned, Ranjha taught to Heer that human love is based on good looks, instead it should be based on being humble and serving the needy. So, you must be prepared to leave the world.

- Dust in the ground: Nouns dust and ground are used as metaphors for the breakdown of Heer's pride and her devotion to Ranjha's advice. On the devotional paths to spiritual development, often the first thing that is attacked is the false sense of self and egotism. Though this happens through a long process, signs of humility and gratitude begin to emerge early on. Heer not only begs Luddan for forgiveness but also shows gratitude towards him for bringing Ranjha into her life. This shows her love and devotion to Ranjha.

- Radiance of sun: Here radiance and sun are used as a metaphor for Ranjha's qualities. Ranjha is compared to the sun showing his radiance, his charm and entrancing effect on people and animals, attracting Heer who devoted herself fully to Ranjha reflecting love and spirituality.

- Clouds of love: Here attributive noun (clouds) for love is used as a metaphor to show the devotion of parents to their children. The dialogue from which this metaphor is selected is spoken by Qazi to Heer, advising her to realize the love of her parents who are a shadow for her to cover and save her from the difficulties of life. 
- Dirt Road: Adjective (dirt) and noun (road) are used metaphorically to signify the parental love and devotion to the children. Moreover, it is a criticism on the system plagued by tribalism, caste discrimination and other prevailing forces, which forbid individuals to make choices free of color and creed.

- Clash of lightning: Clash (noun) and lightning (noun) are used as a metaphor to emphasize the theme of love. Through this metaphor, the devotion of souls of Heer and Ranjha towards each other is explained. Love is represented though the metaphor of light.

- Drug Addiction: The metaphor of intoxication in the form of drug (noun) and addiction (noun) is used to reveal the intensity of love between Heer and Ranjha, the force of which is hard to ignore.

- Spot or Mark on skin: Spot (noun) and mark (noun) combine as a metaphor to emphasize the closeness of their love. A mark on the skin of someone because of the burning and a spot on the mango fruit can never be removed. Similarly, degree of their love is so high that they both can never be away from each other.

- Wild plant: Here the word wild (adjective) and noun (plant) is used as a metaphor to show that lovers only rely on each other. They do not want to be separated from each other. This metaphor is selected from the dialogue spoken by Heer to her father and qazi at the time of nikah ceremony stating her explicit refusal to marry anyone. A wild plant may harm anyone who touches it, similarly, Heer's life without Ranjha would be discordant for the one who touches her.

- Beggar: The word beggar (noun) is used as a metaphor for lover. Uncalled, beggar comes and makes demands. He always needs something that fulfills his desire. When Heer got married, Ranjha went into the forest and met jogi named bulnath, the master of jogis. Ranjha requested him to make him jogi and he asked the reason behind this then Ranjha spoke this word that love demanded this from him, that is why, he wanted to become a jogi.

- Spotless mirror: Here adjective (spotless) and mirror (noun) is used as a metaphor to highlight the submission, compassion and spirituality of true lovers Heer and Ranjha. Spotless mirror is one having neat and clean surface used to show the face. This metaphor is used by Ranjha to speak his heart out that Heer is spotless mirror to his face.

- Vast ocean: Here the word vast (adjective) and ocean (noun) is used as a metaphor to explain the degree of their love. A vast ocean means unusually great in size, amount and scope. The boundary of their love is so vast that it can encompass everything that can be imagined within it. This metaphor also portrays the theme of love clearly.

- Destroyer: Destroyer is used as a metaphor to portray the suffering and consequences of love to Heer. Heer's journey towards Ranjha is fulfilled as she got the permission of her parents to marry him. The dialogue from which this metaphor is taken, is spoken out by Ranjha when he heard the news of Heer's death. Ranjha complains that it is not possible for him to live without her and love is destroyer in the sense that it has taken her life from him.

- Deep sleep: The metaphor highlights the significance of spiritual love of Heer and Ranjha. It is spoken by Ranjha when he was going to kill himself to reach to Heer. For true lovers, permanent place to live is not this temporary world but Heaven. For true lovers there is no importance of worldly existence, as their sole purpose is to meet each other permanently. This is the purpose which is fulfilled by the true lovers Heer and Ranjha at the end of the folktale that portray the theme of love.

Thus, metaphorical analysis of the selected sections of the text reveals how the emotion of love is embedded in the linguistic choices made by the author. The metaphors are emotionally charged colorful ornaments supporting the theme of love construed in the folktale under analysis. Further, the analysis of the above passages at three different levels including lexical, syntactical and discourse level will explain how the choices have been selected and employed by the writer in a particular context of 
folktale to explain theme of love and make meanings coherent in the passages. In the final table, it has been explained that how cohesion and coherence has been created in the passages to explain the theme of love by usage of different discourse markers. 


\subsection{Lexical Level}

Table 1 represents the lexical choices significant to the portrayal of theme of love.

\begin{tabular}{|c|c|c|c|c|c|c|c|c|c|c|c|c|}
\hline Sr.\# & determiners & $\begin{array}{l}\text { Speech } \\
\text { vocatives }\end{array}$ & -ve terms & Colloquial & $\begin{array}{l}\text { Conjuncti } \\
\text { on }\end{array}$ & Idioms & $\begin{array}{l}\text { Hedgi } \\
\text { ng }\end{array}$ & $\begin{array}{l}\text { Prono } \\
\text { un }\end{array}$ & $\begin{array}{l}\text { Metaphors / } \\
\text { similie }\end{array}$ & $\begin{array}{l}\text { Jargon and } \\
\text { Rhetorical meaning }\end{array}$ & Nominals & $\begin{array}{l}\text { Ideological } \\
\text { word }\end{array}$ \\
\hline 1 & the & Waris, & nothing & $\mathrm{Ah}$ & When, and & $\begin{array}{l}\text { Battlefie } \\
\text { ld of } \\
\text { love }\end{array}$ & can & $\begin{array}{l}3^{\text {rd }} \\
\text { perso } \\
n\end{array}$ & $\begin{array}{l}\text { Battlefield, } \\
\text { dream }\end{array}$ & Youth, beauty & - & $\begin{array}{l}\text { Battlefield of } \\
\text { love, dream }\end{array}$ \\
\hline 2 & the & - & Lost, gone & - & and & $\begin{array}{l}\text { Dust in } \\
\text { ground, } \\
\text { at feet of }\end{array}$ & - & $\begin{array}{l}3^{\text {rd }} \\
\text { perso } \\
n\end{array}$ & $\begin{array}{l}\text { Dust in } \\
\text { ground }\end{array}$ & $\begin{array}{l}\text { Command, pride, } \\
\text { grandeur, devotion }\end{array}$ & devotion & $\begin{array}{l}\text { Dust, pride, } \\
\text { grandeur }\end{array}$ \\
\hline 3 & the & Ranjha & Fell & Ranjha & Who , and & $\begin{array}{l}\text { Radianc } \\
\text { e of } \\
\text { sun,fell } \\
\text { at feet }\end{array}$ & - & $\mathrm{i}$ & $\begin{array}{l}\text { Like Radiance } \\
\text { of sun }\end{array}$ & $\begin{array}{l}\text { Honour, } \\
\text { lord,master, } \\
\text { brilliant }\end{array}$ & - & $\begin{array}{l}\text { Belong to lord, } \\
\text { face and sun, } \\
\text { her honour }\end{array}$ \\
\hline 4 & - & you & $\begin{array}{l}\text { Servant } \\
\text { disobedien } \\
\text { ce, dirt }\end{array}$ & Ranjha, & and & $\begin{array}{l}\text { love } \\
\text { clouds, } \\
\text { life as } \\
\text { dirt road }\end{array}$ & - & $\begin{array}{l}3^{\text {rd }} \\
\text { perso } \\
n\end{array}$ & $\begin{array}{l}\text { Clouds of love, } \\
\text { dirt road }\end{array}$ & $\begin{array}{l}\text { Renowned, caste, } \\
\text { mingle }\end{array}$ & $\begin{array}{l}\text { disobedie } \\
\text { nce }\end{array}$ & $\begin{array}{l}\text { Love clouds, } \\
\text { dirt road, } \\
\text { family servant, } \\
\text { renowned } \\
\text { family }\end{array}$ \\
\hline 5 & - & - & Beggar, & - & That, & $\begin{array}{l}\text { Love is } \\
\text { begger }\end{array}$ & want & $\begin{array}{l}\mathrm{I}, 3^{\text {rd }} \\
\text { perso } \\
\mathrm{n}\end{array}$ & beggar & Jogi, beggar & - & Beggar, Jogi \\
\hline 6 & that & her & $\begin{array}{l}\text { Destroy, } \\
\text { deep sleep }\end{array}$ & - & $\begin{array}{l}\text { That's } \\
\text { why }\end{array}$ & $\begin{array}{l}\text { To deep } \\
\text { sleep }\end{array}$ & - & $\begin{array}{l}\mathrm{I}, 3^{\text {rd }} \\
\text { perso } \\
n\end{array}$ & $\begin{array}{l}\text { Destroyer, } \\
\text { deep sleep }\end{array}$ & $\begin{array}{l}\text { Love, deep, } \\
\text { destroy, sleep }\end{array}$ & - & Deep sleep \\
\hline
\end{tabular}




\subsection{Syntactical Level}

Table 2 represents the sentence structure analysis of the types of sentences as well as mood of sentences.

\begin{tabular}{|c|c|c|c|c|c|c|}
\hline $\begin{array}{l}\text { Sentence } \\
\text { No }\end{array}$ & Mood & Complex sentence & Conditional phrase & $\begin{array}{l}\text { Minor } \\
\text { sentence }\end{array}$ & Impersonality $/ 3^{\text {rd }}$ person & $\begin{array}{l}\text { Passive } \\
\text { structure }\end{array}$ \\
\hline 1 & $\begin{array}{ll}\text { Declarative } & \text { and } \\
\text { indicative } & \end{array}$ & $\begin{array}{l}2^{\text {nd }} \text { is complex with } \\
\text { metaphors }\end{array}$ & - & Yes. & No, rather $1^{\text {st }}$ person(i) & $\begin{array}{l}\text { Efforts have } \\
\text { gone waste }\end{array}$ \\
\hline 2 & $\begin{array}{ll}\text { Indicative } & \text { and } \\
\text { imperative } & \\
\end{array}$ & $\begin{array}{l}\text { Yes because she was a } \\
\text { proud lady }\end{array}$ & - & Yes. & $1^{\text {st }}$ person & - \\
\hline 3 & Indicative & $\begin{array}{l}\text { Yes comple with the } \\
\text { usage of metaphors }\end{array}$ & - & - & $3^{\text {rd }}$ person & Grandeur gone \\
\hline 4 & $\begin{array}{ll}\text { Indicative } & \text { and } \\
\text { imperative } & \end{array}$ & - & - & yes & $1^{\text {st }}$ person & - \\
\hline 5 & Imperative & Usage of metaphors & - & - & $1^{\text {st }}$ person & - \\
\hline 6 & $\begin{array}{ll}\text { Imperative and } \\
\text { indicative }\end{array}$ & Usage of metaphor & If it is our destiny & - & $1^{\text {st }}$ person & - \\
\hline 7 & $\begin{array}{l}\text { Imperative and } \\
\text { indicative }\end{array}$ & $\begin{array}{l}\text { Yes,usage } \\
\text { coordinating } \\
\text { conjunction }\end{array}$ & When you know & - & $1^{\text {st }}$ person & $\begin{array}{lr}\text { Was } & \text { already } \\
\text { made } & \text { with } \\
\text { ranjha } & \\
\end{array}$ \\
\hline 8 & Declarative & - & That's why & - & $1^{\text {st }}$ person & - \\
\hline 9 & Indicative & A bit & no & $\begin{array}{l}\text { We both are } \\
\text { true lovers }\end{array}$ & $3^{\text {rd }}$ person, 1st person & - \\
\hline 10 & Declarative & - & That's why & Yes. & $1^{\text {st }}$ person & - \\
\hline
\end{tabular}




\subsection{Discourse Level}

Table 3 represents the choices showing structural and non-structural cohesion as well as the significant discourse markers.

\begin{tabular}{|c|c|c|c|c|c|c|c|}
\hline No & Conj. & $\begin{array}{l}\text { Anaphora/ } \\
\text { cataphora }\end{array}$ & Colloquials & Conditionals & $\begin{array}{l}\text { Idiomatic } \\
\text { Expression }\end{array}$ & Metaphor/hyperbole & Hedging \\
\hline 1 & And, & This $\rightarrow$ folktale & Warsa, & - & $\begin{array}{l}\text { Precious pearls } \\
\text { in a twine of } \\
\text { munj, }\end{array}$ & $\begin{array}{l}\text { Precious, pearls, twine of } \\
\text { munj }\end{array}$ & - \\
\hline 2 & When, and & - & $\mathrm{Ah}$ & - & $\begin{array}{l}\text { Battlefield of } \\
\text { love }\end{array}$ & Battlfoeld,dream & can \\
\hline 3 & And & - & - & - & $\begin{array}{l}\text { Dust in } \\
\text { ground,at feet } \\
\text { of }\end{array}$ & Dust in ground & - \\
\hline 4 & Who, and & His $\rightarrow$ ranjha & ranjha & - & $\begin{array}{l}\text { Radiance of } \\
\text { sun,fell at feet }\end{array}$ & Like Radiance of sun & - \\
\hline 5 & And & - & Ranjha, & - & $\begin{array}{l}\text { love clouds,life } \\
\text { as dirt road }\end{array}$ & Clouds of love,dirt road & - \\
\hline 6 & Then,who,or & $\begin{array}{l}\text { It } \rightarrow \text { destiny } \\
\text { They } \rightarrow \text { true lovers }\end{array}$ & - & $\begin{array}{l}\text { If it is our } \\
\text { destiny }\end{array}$ & & $\begin{array}{l}\text { Clash of } \\
\text { lightining,mark,spot,drug } \\
\text { addict }\end{array}$ & Can \\
\hline 7 & And,when,then & $\begin{array}{l}\text { Stranger } \rightarrow \text { saeeda } \\
\text { khera }\end{array}$ & Nikkah & $\begin{array}{l}\text { When you } \\
\text { know }\end{array}$ & $\begin{array}{l}\text { Ife is Wild } \\
\text { plant,dissolve }\end{array}$ & Wild plant, & can \\
\hline 8 & That, & - & - & That's why & Love is begger & begger & want \\
\hline 9 & And & We $\rightarrow$ heer and Ranjha & - & No & $\begin{array}{l}\text { Vast ocean of } \\
\text { love,spotless } \\
\text { mirror }\end{array}$ & Spotless mirror,vast ocean & - \\
\hline 10 & That's why & Her $\rightarrow$ Heer & - & That's why & To deep sleep & Destroyer,deep sleep & - \\
\hline
\end{tabular}


The second research question was about the power relations between men and women portrayed throughout the folktale Heer Ranjha.

The selected passages from the folktale are analysed in detail according to their social and cultural background. Nine passages are selected to signify the power relationships between men and women:

"You eat the bread of idleness and drink two men's share of butter and milk.Verily you were your father's darling but the very shame of your mother.You are the only blot on our family."

These are the words spoken by the wives of Ranjha's brothers to Ranjha. As their husbands worked hard all the day in the fields but Ranjha remains aloof. He was the favourite son of his father but after the death of his father, these women show their jealousy towards him. They were of the jealous and cunning nature and they only care for materialistic things rather than relations as they did conspiracy with the help of their husbands and gave bribe to Qazi for dividing the land. Relationship between men and women was not based on blood rather it was based on the materialistic values. The relationship between men and women is highlighted in next dialogue which is answer of Ranjha to this type of behaviour of his brother's wives. So, the power goes with the women, not men.

"It is truly written in the Holy Qur'an: "Women are ever deceivers." Did not women befool Raja Bhoj, put a bit in his mouth and drive him like a donkey round the palace? It is you who have stirred up strife, it is you who have separated me from my brethren. You women make men into rams so that they fight with one another.”

In answer to the passage written above, Ranjha has spoken these words through which he has highlighted the real cause of throwing him away from his brothers and giving him such barren land in his share. He exemplifies this line by giving the reference of Raja Bhoj from history. He has highlighted in the passage that women are for breach in family. So it is clear that in that vey time, relationship between men and women was not satisfactory; women do not care for the blood rather they care for wealth, power and status. Similarly, men were not having the sound relationship with them as they were of the view that they are most cunning and jealous creature that draw lines between the relatives and create conflict between men.

"You black-faced rogue, why have you deified my couch? Whom have you allowed to sleep on my bed? Have you no respect for me or fear of God that you have done this thing?"

Heer directs these lines towards Luddan when she came to her garden with her girl friends and found that Ranjha was sleeping at her couch. As she was the most beautiful, proud and pampered daughter of a feudal chief, Chuchak Sial,she was not expecting someone even to touch her bed. So she bursts out at Luddan and abused him by calling black faced rough in anger which clearly signify that women of that time were very proud of having status, power and wealth in society and, because of that she was so proud of her status that she gave warning to Luddan that in disobeying her the curse of God will be on him. Here power lies in her lines as she belongs to legendary caste.

"Spare me, Lady, I am innocent. Even tyrants fear God.” 
This line is spoken by Luddan in reply of above passage which emphasises low social status of Luddan. He said that it is the duty of everyone person to fear God whether he is poor or rich. So from these two passages the relationships between men and women are demonstrated. Females belonging to higher caste and renowned family were allowed to use men according to their ways but the men were restricted in such schemes against women.

"Be gentle with me, sweetheart. This world is a dream. Even you, proud lady, will have to die. You should not be unkind to strangers or treat poor men with haughtiness. Take back your couch and quilt and I will depart hence and be no more seen.”

These lines are spoken by Ranjha to Heer in their first meeting. As she was pampered daughter of Chuchak Sial, she tried to beat Ranjha as he was sleeping on her couch but at the spot he woke up and spoke these lines to her. As she was proud lady so it was difficult for her to listen the words of anyone but these words of Ranjha got influence upon her. Most importantly, in the lines there is fact about the relations of men and women as men were very polite as is Ranjha in the dialogue but women of renowned families were arrogant especially Heer. Women of renowned families had authority on men of that time. Ranjha spoke very politely to her and told her the human love is not based on good looks and beauty rather it is based on being humble and serving the needy. In this dialogue, it is demonstrated that she was having power, status as she was proud and vain but Ranjha has told the real worth of human love.

"Verily your deceit is great. Satan is the Lord of evil spirits and women. Women falsify the truth and feel no shame. The word of women, boys, hemp smokers and bhang smokers cannot be trusted."

This is the passage spoken by Ranjha to Heer at the time when she came with bread, rice and milk to serve him in the forest. The passage demonstrates gender position as suspicious and less trustworthy. The relationship of men with women was not impressive as Ranjha compares women with evil spirits along with pupils of satan the most cunning and jealous creature. The women were not given the value. They are similar to 'bhang' smokers that do not know when they are done with smoking and bhang. They cannot be trusted as they will tell the secrets to others. Similarly women were not considered loyal as they reveal the hidden facts.

"Daughters who are disobedient to their parents are not daughters but prostitutes. You bad girl, you should be drowned in the deep stream for causing such a scandal. Grown up daughters who venture outside their father's house should be thrown down the wells. Why have you cut off the nose of the family."

These lines are self-explanatory as are spoken to Heer by her mother at the time when she came to know about the love between Ranjha and her daughter. As she belongs to higher caste it was not expected from her as women of that time were not having so much authority and power to love anyone and marry that person. Similarly it happens to Heer, when mother comes to know about the scandal of Heer with Ranjha, she warns her about the consequences that women are not given permission to act like this as if that news will come under her father or her brothers notice the consequences would be dangerous. It means the power goes not with the women rather with the men who decide to whom their daughters, sisters are going to marry. Here Heer's mother scorns her as she has changed the 
whole scenario by loving Ranjha and has made a whole for herself because she will not be permitted to marry him .If she will do like this it will be dishonor for the family and her brother and father will kill her. So it is explicit from the lines that women did not have choice to take decisions of her life, rather she depended upon males willingly or forcefully.

"Your daughter is a bad girl and our hearts are burnt with shame like roasted meat. If we speak to her she is insolent to us. She has the pride of a princess. She is a bad example to the village and we are beginning to be anxious about our own daughters.”

This is the passage spoken to Heer's mother by the women of the village about her scandal with Ranjha. Heer becomes notorious for loving Ranjha that other women of the village were afraid that one day their daughter will follow Heer in this respect. They claim to her mother and request to stop her at home so that their daughters can live at their homes. Here again the question of power relationship goes in the favor of men and women have to rely on that fate.

"It is not becoming for the daughter of Chuchak to talk to cowherds and mingle up with the family servant like Ranjha. You should sit in the assemblies of women in their spinning parties. Those who do not obey their parents will be burnt alive. If we were to condemn you, you will be done to death at once. You should obey the orders of your religion, if you wish to live.

These lines are uttered by Qazi at the time of marriage ceremony of Heer. Here it is significant that Heer who was praised and loved by everyone in the village, now has become the source of humiliation and disgrace because she has a love relation with Ranjha. Qazi is scolding her by saying that she should obey her parents and be away from the family servant shows that women were not allowed to marry a person of their own choice because of the system plagued by tribalism, caste discrimination and other patterns of society. The role of Qazi and Mullah is also criticized in the socio-cultural setting of this scene.
"Why abuse women? It is men who are bad. They are not content with their lawful wives but go hunting for the petticoats belonging to other men. It is men who are shameless and black faced. They come to their senses when they lose their wives and then they say, "It is Destiny." They sit at the feet of Mullahs and listen to the doctrines of Hypocrisy. A home looks well with a wife even as lamps look well on a dark night.

These lines are spoken to Ranjha by Sehti; sister of Saida khera to whom Heer was married. Actually these lines are answers to the lines spoken by Ranjha about the women when he was in the disguise of a Jogi and he sings that it is the women that caused the expulsion of Adam from Heaven and those who remain aloof from women ,they have got the ways to reach towards God as thay have become saints. Throughout the line it has become evidently clear that power lies mostly with men and women are suppressed.

\section{Conclusion}

This research revolved around two questions. The first question was about the metaphors that portray the theme of love as well as the analysis at three different levels. It is concluded, Heer-Ranjha is 
an unrequited immortal love story and both Heer and Ranjha are the true legendry lovers. Keeping in view all the seventeen metaphors and their explanation and analysis of passages at three different levels, it is evident that linguistic choices are significant vehicles of thought and emotion.

As an answer to the second question, it can be concluded that throughout the story, the men are shown to exercise power and the women are submissive and under authority. From gender perspective, it is significant to approach feminine voice in folk tale which provides a realistic socio-cultural stage for the construal of gendered identities and their mutual relations.

This research is significant in opening up analyses in the domain of folk tales and the lexical categories of discourse studies. Furthermore, it can be a useful beginning to compare the power relation between genders in the past and the contemporary times through the stylistic study of folk tales.

\section{References}

Bachtarzi, A. (2010). Men's Relationships in D.H. Lawrence's Sons and Lovers.[Master's thesis] Mentouri University Constantine

Butler, J. (2007). Gender Trouble: Feminism and the Subversion of Identity. Routledge.

Cherland, M. (2008) Harry's Girls: Harry Potter and the Discourse of Gender. Journal of Adolescent \& Literacy 52(4):273-282. DOI: 10.1598/JAAL.52.4.1

Fairclough, N. (2015). Language and Power (3rd edn.). London: Rutledge.

Foghel, B. (2013). Patterns and Representations of Shakespearean Love: Hubris, Infatuation, Agape in Hamlet. Gender Studies Vol. 11 (1).

Lakoff, G., Johnson M. (1980). Metaphors We Live By. Chicago: Chicago University Press.

Lazar, M. M. (2007). Feminist Critical Discourse Analysis: Articulating a Feminist Discourse Praxis1. Critical Discourse Studies 4 (2):141-164.

Mahboob, A. (2015). Identity Management, Language Variation and English Language Textbooks: Focus on Pakistan. In Dwi Noverini Djenar, Ahmar Mahboob, Ken Cruickshank (Eds.) Language and Identity Across Modes of Communication. Boston: Walter de Gruyter.

Mehmood,A.,Amber,R., Ameer, S. \& Faiz, R. (2014). Transitivity analysis: representation of love in Wilde's The Nightingale and the Rose. European Journal of Research in Social Sciences Vol. 2 (4)

Mills, S. (1995). Feminist stylistics. London: Routledge.

Musolff, A. (2012). The study of metaphor as part of critical discourse analysis, Critical Discourse Studies, 9:3, 301-310, DOI: 10.1080/17405904.2012.688300.

Searle, J R. (1980). Speech Act Theory and Pragmatics. USA: Kluwer Boston Inc.

Tannen, D. (1994). Gender and discourse. New York: Oxford University Press.

Usborne, C.F. (1973). The Adventures of Heer Ranjha. A British Commonwealth (edn.) London: Owen. 203S. UNESCO.

White, P. (1997). Death, disruption and the moral order: the narrative impulse in mass-media 'hard news' reporting. In F. Christie, \& J. R. Martin (Eds.), Genre and institutions social Processes in the workplace and school (pp. 101-133). New York: Continuum. 